\title{
Quantifying the Nitrogen and Water Stress of Maize Using Spectral Vegetation indices
}

\author{
K. Ramachandiran ${ }^{1 *}$, S. Pazhanivelan' ${ }^{2}$, M. Mohamed Amanullah' ${ }^{1}$, V. Geethalakshmi ${ }^{3}$, R. Sivasamy ${ }^{2}$ and N. Asoka Raja ${ }^{1}$ \\ ${ }^{1}$ Dept. of Agronomy ${ }^{2}$ Dept. of Remote Sensing and GIS and ${ }^{3}$ Agro-climate Research Center, Tamil Nadu Agricultural \\ University, Coimbatore, Tamilnadu (641 003), India
}

\section{Article History}

Manuscript No. AR1367a

Received in $31^{\text {st }}$ March, 2015

Received in revised form $24^{\text {th }}$ January, 2016

Accepted in final form $5^{\text {th }}$ February, 2016

\section{Correspondence to}

${ }^{*} E$-mail: krchandiran@gmail.com

\section{Keywords}

Remote sensing, spectral indices, nitrogen, water, stress, maize

\begin{abstract}
Numerous spectral vegetation indices have been developed to characterize vegetation canopies. These indices will easily predict or quantify the plant stress at earlier with help of remote sensing techniques. Field experiments were conducted at the Tamil Nadu Agricultural University, Coimbatore, Tamilnadu, India during rabi 2013 with maize crop. To ensure the stressed environment, the crop was subjected to two irrigation levels (CPE: $0.80,0.50)$ and five staggered nitrogen levels $(0,50,75,100$ and $125 \%$ of RDN. The experiment was laid out in FRBD with three replication. Measured spectral reflectance curve of maize exhibited a broad low intensity peak centered in the green region at $550 \mathrm{~nm}$ and a sharp rise starting at about $685 \mathrm{~nm}$ to a plateau in the vicinity of $762 \mathrm{~nm}$ under unstressed environment created with irrigation at $0.80 \mathrm{IW} / \mathrm{CPE}$ ratio and fertilizer application at $100 \% \mathrm{RDN}$. Significant differences in reflectance were established for nitrogen and water stress at green and NIR region. The spectral indices viz., NDVI, GNDVI, RVI, LCI, IR-RED and SR recorded higher value on unstressed maize crop and plants under stress caused reduction in value of these indices at 60 and 90 DAS. All the spectral vegetation indices correlated positively with LAI and SPAD values with a correlation coefficient above 0.80 at both stages. These results highly support the ability of spectral vegetation indices to quantify the combined effect of nitrogen and water stress on maize too earlier through remote sensing.
\end{abstract}

\section{Introduction}

Maize (Zea mays L.) is one of the most versatile cereal crops having wider adaptability under varied agro-climatic conditions. Maize is the third most important cereal crop in India after rice and wheat. Its importance lies in the fact that it is not only used for human food and animal feed but at the same time it is also widely used for corn starch industry, corn oil production, baby corns etc., It accounts for $9 \%$ of total food grain production in the country. In India maize is cultivated in an area of 9.4 mha with a production of $23 \mathrm{mt}$ and productivity of $2.5 \mathrm{t} \mathrm{ha}^{-1}$ in 2013-14 (Anonymous, 2014).

Maize crop growth is affected by different stresses viz., water, pest, weed, nutrients, etc., which reduce the productivity. Among the various inputs, water and fertilizer (nutrients) are considered as the two key inputs making maximum contribution to maize productivity. Out of the three macro elements (NPK), application of nitrogen fertilizer brings out the highest yield increase in maize (Szeles et al., 2012). Stresses come from a range of factors that limit the potential growth of canopies. Evaluation of the stress level to which plants are subjected to is therefore vital information required both for the quantification of consequences on production and for taking action for their mitigation.

Remote sensing is a better method to detect and quantify the impact of plant stress compared to visual techniques because a vegetative unit can be repeatedly, objectively, and nondestructively examined in a fast, robust, accurate, and inexpensive way (Mirik et al., 2012). Earlier research on applications of remote sensing in agriculture focused on the visible and near-infrared regions of the spectrum. These studies found an inverse relationship between spectral reflectance and radiances in the red region of the electromagnetic spectrum and in situ chlorophyll density, but a direct relationship was found to exist between spectral reflectance and radiances in the near-infrared region and the green leaf density.

The launch of new hyperspectral remote sensing satellites, the focus of current research has been shifted to investigate the possibilities of hyper spectral remote sensing in crop monitoring. A hyper spectral imaging system acquires information in more than 100 very narrow, defined continuous 
spectral bands. In this system, reflected radiation from any specified target can be obtained continuously, making it possible to gain detailed information on the materials at any target (Lillesand and Kiefer, 2000). These narrow wavebands make hyper spectral remote sensing systems as powerful tools that have the potential to avoid time consuming and labour intensive ground data collection methods. Hyper spectral remote sensing techniques allow the early detection of vegetation stress, before the appearance of visible symptoms (Panigada et al., 2010). Using that absorption and spectral reflection characteristics of vegetation researchers has defined many vegetation indices for monitoring vegetation parameters. Spectral vegetation indices were designed to evaluate vegetation condition, foliage, cover, phenology and processes in addition to be used for land cover classification, climate and land use detection, drought monitoring and habitat loss (Padilla et al., 2011). More recently, Mirik et al. (2012) discussed that spectral vegetation indices are mathematical expressions involving reflectance values from different part of the electromagnetic spectrum, aimed to optimize information and normalize measurements made across varied environmental conditions.

The advent of spectral mapping and identification of vegetation by remote sensing methods, it assumes importance to study crop stress using remote sensing techniques in maize under different nitrogen levels and water stress conditions. Keeping these in view an experiment was planned for earlier determination of nitrogen and water stress with hyper spectral reflectance and vegetation indices on maize with the objectives to investigate the possibility of using hyper spectral observations to detect combined effects of various stress especially water and nitrogen and to quantity the effect of nitrogen and water stress on maize using spectral vegetation indices.

\section{Materials and Methods}

\subsection{Study area}

A field experiment was conducted at Tamil Nadu Agricultural University, Coimbatore, Tamilnadu, India during rabi 2013 with maize crop (TNAU maize hybrid Co 6). The site of experiment is located at $\mathrm{N}^{\prime} 1^{\circ} 0^{\prime} 33.4^{\prime \prime} \mathrm{E} 76^{\circ} 56^{\prime} 25.7^{\prime \prime}$ and 430.5 MSL in a subtropical belt. The soil is sandy clay loam in texture and the soil is alkaline in reaction with a pH of 8.41. The soil was medium in organic carbon $(0.62 \%)$, Low available nitrogen $\left(186 \mathrm{~kg} \mathrm{ha}^{-1}\right)$, medium available phosphorus $\left(13 \mathrm{~kg} \mathrm{ha}^{-1}\right)$ and high available potassium $\left(367 \mathrm{~kg} \mathrm{ha}^{-1}\right)$. The soil moisture retention is $24.3 \%$ at 0.33 bars and $10.2 \%$ at 15 bars.

\subsection{Experimental design}

To ensure the stressed environments, the crop was subjected to two irrigation levels and five staggered nitrogen levels. The experiment was laid out in RBD (Factorial) with three replication and the details of the treatments are as follows. The irrigation regimes were $\mathrm{W}_{1}$ (IW/CPE: 0.80) and $\mathrm{W}_{2}$ (IW/ CPE: 0.50) (IW=5 cm) and the nitrogen levels were $\mathrm{N}_{0}$ : No nitrogen, $\mathrm{N}_{1}: 50 \%$ RDN, $\mathrm{N}_{2}: 75 \%$ RDN, $\mathrm{N}_{3}: 100 \%$ RDN and $\mathrm{N}_{4}: 125 \%$ RDN (RDN: Recommended dose of nitrogen). The general recommended dose of fertilizers for hybrid maize is 250:75:75 NPK kg ha-1 as per the package of practice suggested by the Department of Agriculture, Govt. of Tamilnadu and Tamil Nadu Agricultural University, Coimbatore-3.

\subsection{Spectral reflectance measurements}

Hyper spectral data were collected from plant canopy by using GER 1500 portable spectroradiometer which has 512 channels ranging from $350-1050 \mathrm{~nm}$ with $1.5-3.2 \mathrm{~nm}$ bandwidths. The reflectance measurements were made on sunny days. The field of view (FOV) was $25^{\circ}$ and the distance between the optical head of the spectroradiometer and the top of the plant was kept at $1 \mathrm{~m}$ for the all observations. Calibration of the radiometer was done with the help of barium sulphat coated plate in the field before and after taking canopy reflectance measurement. The canopy reflectances were computed as the ratio of canopy radiances to the radiance from the white reference plate. The spectral characteristics of the crop were measured at 60 and 90 days after sowing.

\subsection{Spectral vegetation indices}

Spectral reflectance indices viz., NDVI, GNDVI, RVI, LCI, IR-RED and SR were calculated, where $\mathrm{R}$ and subscript number indicate the light reflectance at specific wavelength (in nm) (Table 1). The reflectance data were transformed in to

Table 1: Spectral indices and ratio of spectral wavebands used to differentiate nitrogen and water stress in hybrid maize

\begin{tabular}{|c|c|c|c|}
\hline Index & $\begin{array}{l}\text { Abbre- } \\
\text { viation }\end{array}$ & Formula & Reference \\
\hline $\begin{array}{l}\text { Normalized } \\
\text { difference } \\
\text { vegetation index }\end{array}$ & NDVI & $\begin{array}{l}\left(\mathrm{R}_{850}-\mathrm{R}_{670}\right) / \\
\left(\mathrm{R}_{850}+\mathrm{R}_{670}\right)\end{array}$ & $\begin{array}{l}\text { Rouse et al., } \\
1973\end{array}$ \\
\hline Green NDVI & $\begin{array}{l}\text { GND- } \\
\text { VI }\end{array}$ & $\begin{array}{l}\left(\mathrm{R}_{780}-\mathrm{R}_{550}\right) / \\
\left(\mathrm{R}_{780}+\mathrm{R}_{550}\right)\end{array}$ & $\begin{array}{l}\text { Aparicio et al., } \\
2000\end{array}$ \\
\hline $\begin{array}{l}\text { Ratio vegetation } \\
\text { index }\end{array}$ & RVI & $\left(\mathrm{R}_{927} / \mathrm{R}_{687}\right)$ & Thenkabail et \\
\hline $\begin{array}{l}\text { Leaf Chlorophyll } \\
\text { index }\end{array}$ & LCI & $\begin{array}{l}\left(\mathrm{R}_{850}-\mathrm{R}_{710}\right) / \\
\left(\mathrm{R}_{850}+\mathrm{R}_{680}\right)\end{array}$ & al., 2000 \\
\hline $\begin{array}{l}\text { Infrared-red } \\
\text { index }\end{array}$ & $\begin{array}{l}\text { IR- } \\
\text { RED }\end{array}$ & $\left(\mathrm{R}_{789} / \mathrm{R}_{663}\right)$ & $\begin{array}{l}\text { Genc et al., } \\
2011\end{array}$ \\
\hline Simple ratio & SR & $\left(\mathrm{R}_{900} / \mathrm{R}_{680}\right)$ & $\begin{array}{l}\text { Gitelso- } \\
\text { nand Mer- } \\
\text { zlyak,1996 }\end{array}$ \\
\hline
\end{tabular}


vegetation indices and used to distinguish nitrogen and water stress severity in maize.

\section{Results and Discussion}

\subsection{Spectral signature}

In general, measured spectral reflectance curve of maize exhibited a broad low intensity peak centered in the green region at $550 \mathrm{~nm}$ and a sharp rise starting at about $685 \mathrm{~nm}$ to a plateau in the vicinity of $762 \mathrm{~nm}$. Spectral reflectance of maize varied from different irrigation regimes and changed with nitrogen levels. Irrigation at IW/CPE ratio 0.80 with $100 \%$ RDN (unstressed) of maize showed that low reflectance in visible region (400 to $700 \mathrm{~nm}$ ) and high in near infra red (NIR) region (700 to 900). Under stressed condition the reflectance was high in visible region and low in NIR region at IW/CPE ratio 0.50 with no nitrogen compare to unstressed maize (Figure 1). Similar reflectance pattern of maize crop was observed at 60 and 90 DAS. Plant stress that causes reduction in chlorophyll leads to an increase in light reflected in the visible range (400-700 nm). Conversely, percent reflection in the NIR region (740-100 nm) is reduced as internal leaf structure degenerates. Reflectance is low in both the blue and red regions of the spectrum, due to absorption by chlorophyll for photosynthesis, also known as the chlorophyll absorption bands. It has a peak at the green region which gives rise to the green colour of vegetation. In the NIR region, the reflectance is much higher than that in the VIS band due to the cellular structure in the leaves (Krezhova, 2011).

Spectral signature from different nitrogen levels within the irrigation regimes also varied. While similar reflectance pattern of maize was observed under nitrogen levels, the percent of reflectance was high in visible region and low in NIR region with no nitrogen as compare to all other nitrogen levels within irrigation regimes (Figure 2 and 3). Whereas the spectral signature slightly decreased in visible spectrum and increased in NIR region when nitrogen dose was increased to 50,75 and $100 \%$ RDN of maize crop. As in line with the trend, spectral reflectance of maize crop at $125 \% \mathrm{RDN}$ was found that to be very low in visible region and very high in NIR region. Similar reflectance pattern of maize crop was observed at 60 and 90 DAS. Light reflected by vegetation in the visible region of the spectrum is predominantly influenced by the presence of chlorophyll pigments in the leaf tissues, which have been found to relate to the concentration of leaf nitrogen. Increase in nitrogen dose, the chlorophyll content increased significantly (Pradhan et al., 2013). There was a similar trend to reflectance behavior of water stress levels using chlorophyll readings. Reflectance spectra indicated that water stressed corn plants absorbed less light in the visible and more light in the NIR regions of the spectrum than the less water stressed

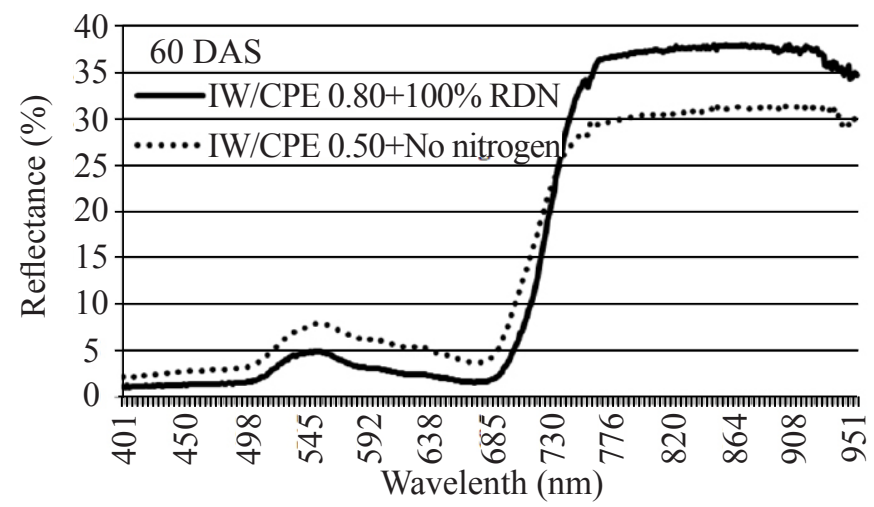

Figure 1: Spectral signature characters of unstressed (IW/CPE ration: $0.80+100 \% \mathrm{RDN}$ ) and stressed (IW/CPE ratio: $0.50+$ no nitrogen) maize crop at $60 \mathrm{DAS}$

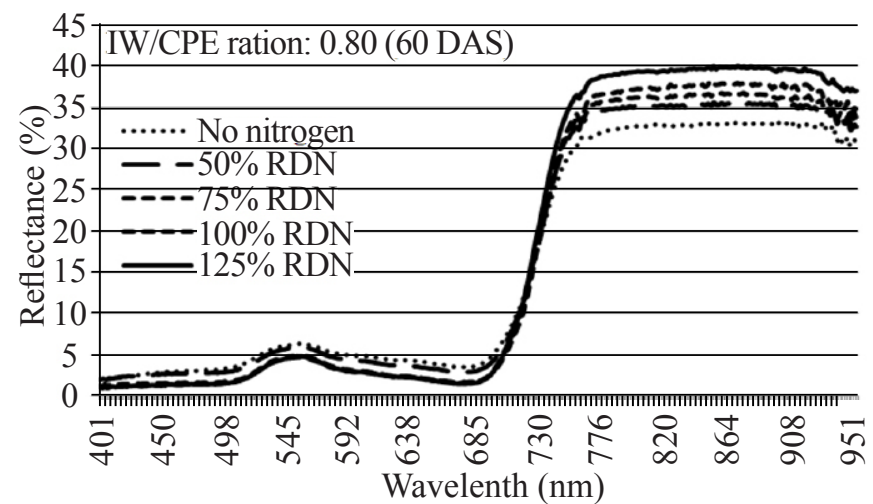

Figure 2: Spectral signature characters of maize crop with irrigation at IW/CPE ration: 0.80 and different nitrogen levels viz., No nitrogen, $50 \%$ RDN, $75 \%$ RDN, $100 \%$ RDN and $125 \% \mathrm{RDN}$ at $60 \mathrm{DAS}$

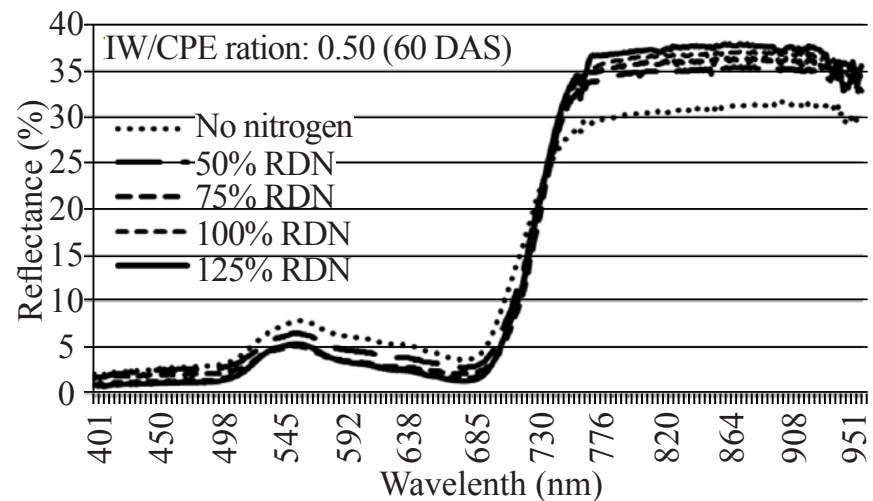

Figure 3: Spectral signature characters of maize crop with irrigation at IW/CPE ration: 0.50 and different nitrogen levels viz., No nitrogen, 50\% RDN, 75\% RDN, 100\% RDN and $125 \% \mathrm{RDN}$ at $60 \mathrm{DAS}$

and unstressed plants. Lower reflectance spectra in the NIR region from stressed leaves when compared to lesser stress or unstressed corn leaves indicated that water stress also reduced green leaf area (Genc et al., 2013).

Among different irrigation regimes of 0.50 and $0.80 \mathrm{IW} / \mathrm{CPE}$ 
radio,water stressed maize crop (IW/CPE: 0.50) had higher reflectance than unstressed maize (IW/CPE:0.80) in the visible spectrum in contrast to much higher reflectance from unstressed plants when compared to lower reflectance from stressed plants in the NIR spectrum at 60 and 90 DAS as also reported by Elmetwalli et al. (2012). The increase of moisture stress in plant caused an increase in red band reflection and decrease in the near infrared spectral band. The increase in reflectance in the red region is caused by the reduced activity of chlorophyll leading to decrease in absorption. While in the near infrared region, the decline in reflectance is due to the reduced turgidity of spongy-mesophyll layer in rainfed crop compared to the turgidity levels of fully irrigated crop (Jayasree et al., 2013).

\subsection{Spectral vegetation indices}

The temporal variation in different vegetation indices of stress

\begin{tabular}{|c|c|c|c|c|c|c|c|c|c|c|c|c|}
\hline \multicolumn{13}{|c|}{$\begin{array}{l}\text { Table 2: Hyper spectral vegetation indices of nitrogen and water } \\
\text { stress in hybrid maize at } 60 \text { and } 90 \text { DAS }\end{array}$} \\
\hline \multicolumn{13}{|c|}{$60 \mathrm{DAS}$} \\
\hline \multirow{2}{*}{ 总 } & \multicolumn{2}{|c|}{ NDVI } & \multicolumn{2}{|c|}{$\begin{array}{l}\text { Green } \\
\text { NDVI }\end{array}$} & \multicolumn{2}{|c|}{ RVI } & \multicolumn{2}{|c|}{ LCI } & \multicolumn{2}{|c|}{ IR-RED } & \multicolumn{2}{|c|}{ SR } \\
\hline & $\mathrm{W}_{1}$ & $\mathrm{~W}_{2}$ & $\mathrm{~W}_{1}$ & $\mathrm{~W}_{2}$ & $\mathrm{~W}_{1}$ & $\mathrm{~W}_{2}$ & $\mathrm{~W}_{1}$ & $\mathrm{~W}_{2}$ & $\mathrm{~W}_{1}$ & $\mathrm{~W}_{2}$ & $\mathrm{~W}_{1}$ & $\mathrm{~W}_{2}$ \\
\hline $\mathrm{N}_{0}$ & $\bar{\infty}$ & $\stackrel{\infty}{\infty}$ & $\stackrel{\infty}{0}$ & nุ? & $\underset{\infty}{\stackrel{\infty}{\infty}}$ & $\stackrel{\text { ?ִ }}{r}$ & $\stackrel{5}{0}$ & $\tilde{n}$ & $\begin{array}{l}\text { ळे } \\
\text { ஸे }\end{array}$ & $\begin{array}{l}\text { oे } \\
\text { iे }\end{array}$ & ing & तે \\
\hline $\mathrm{N}_{1}$ & 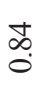 & $\begin{array}{l}+ \\
\infty \\
0\end{array}$ & $\stackrel{ }{i}$ & $\stackrel{\infty}{\circ}$ & $\begin{array}{l}\stackrel{0}{\infty} \\
\stackrel{0}{0}\end{array}$ & $\stackrel{\infty}{\stackrel{0}{0}}$ & $\overrightarrow{0}$ & $\stackrel{8}{\circ}$ & $\hat{\bar{m}}$ & $\frac{n}{m}$ & $\stackrel{\infty}{\stackrel{\infty}{=}}$ & $\stackrel{\mathscr{\infty}}{=}$ \\
\hline $\mathrm{N}_{2}$ & $\bar{\sigma}$ & $\stackrel{\infty}{\infty}$ & $\stackrel{\hat{\imath}}{0}$ & $\stackrel{0}{0}$ & $\stackrel{\sim}{\stackrel{\sim}{2}}$ & $\begin{array}{l}\infty \\
\stackrel{\infty}{ \pm}\end{array}$ & $\stackrel{\infty}{0}$ & $\stackrel{i}{0}$ & $\begin{array}{l}\stackrel{\infty}{\sim} \\
\stackrel{m}{\oplus}\end{array}$ & $\stackrel{\infty}{\stackrel{m}{m}}$ & $\begin{array}{l}\infty \\
\stackrel{\sim}{0}\end{array}$ & तై \\
\hline $\mathrm{N}_{3}$ & $\hat{\sigma}$ & $\bar{\sigma}$ & $\stackrel{\hat{\imath}}{0}$ & $\stackrel{0}{0}$ & 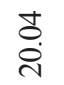 & $\begin{array}{l}\underset{\infty}{\infty} \\
\stackrel{\infty}{\circ}\end{array}$ & $\stackrel{\infty}{\stackrel{0}{0}}$ & $\stackrel{t}{\stackrel{t}{0}}$ & $\begin{array}{l}\text { లై } \\
\text { nై }\end{array}$ & $\begin{array}{l}\bar{m} \\
\stackrel{m}{*}\end{array}$ & $\begin{array}{l}\bar{\vartheta} \\
\tilde{\lambda}\end{array}$ & $\begin{array}{l}50 \\
\stackrel{i}{0}\end{array}$ \\
\hline $\mathrm{N}_{4}$ & $\delta$ & کे & $\stackrel{\infty}{\stackrel{0}{0}}$ & $\stackrel{t}{\stackrel{0}{0}}$ & $\underset{\infty}{\infty}$ & ڤे & $\stackrel{\infty}{0}$ & $\stackrel{n}{a}$ & $\underset{m}{\stackrel{n}{n}}$ & $\begin{array}{l}\hat{n} \\
i n\end{array}$ & $\begin{array}{l}\stackrel{\circ}{\circ} \\
\dot{d}\end{array}$ & 气̆ \\
\hline \multicolumn{13}{|c|}{90 DAS } \\
\hline \multirow{2}{*}{ 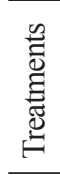 } & \multicolumn{2}{|c|}{ NDVI } & \multicolumn{2}{|c|}{$\begin{array}{l}\text { Green } \\
\text { NDVI }\end{array}$} & \multicolumn{2}{|c|}{ RVI } & \multicolumn{2}{|c|}{ LCI } & \multicolumn{2}{|c|}{ IR-RED } & \multicolumn{2}{|c|}{ SR } \\
\hline & $\mathrm{W}_{1}$ & $\mathrm{~W}_{2}$ & $\mathrm{~W}_{1}$ & $\mathrm{~W}_{2}$ & $\mathrm{~W}_{1}$ & $\mathrm{~W}_{2}$ & $\mathrm{~W}_{1}$ & $\mathrm{~W}_{2}$ & $\mathrm{~W}_{1}$ & $\mathrm{~W}_{2}$ & $\mathrm{~W}_{1}$ & $\mathrm{~W}_{2}$ \\
\hline $\mathrm{N}_{0}$ & ?̊? & $\tilde{n}$ & f. & f̊ & $\vec{\sim}$ & $\underset{\text { r }}{\stackrel{\Delta}{ }}$ & $\stackrel{n}{\tilde{\theta}}$ & $\stackrel{m}{0}$ & $\stackrel{n}{a}$ & $\stackrel{\infty}{m}$ & in & $\stackrel{\infty}{\overbrace{n}^{\infty}}$ \\
\hline $\mathrm{N}_{1}$ & $\begin{array}{l}\widetilde{\sigma} \\
\text { రె. }\end{array}$ & $\tilde{n}$ & $\bar{n}$ & గnç & $\stackrel{m}{m}$ & $\stackrel{n}{m}$ & 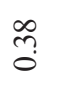 & $\stackrel{\infty}{\overbrace{0}^{\infty}}$ & $\begin{array}{l}\stackrel{\infty}{u} \\
\ddot{v}\end{array}$ & $\stackrel{\substack{m \\
\sim}}{\sim}$ & $\stackrel{\bullet}{\underset{f}{+}}$ & $\underset{\dot{m}}{\vec{r}}$ \\
\hline $\mathrm{N}_{2}$ & $\stackrel{\nabla}{\circ}$ & ठ্ট: & $\stackrel{\infty}{n}$ & $\stackrel{n}{n}$ & $\begin{array}{l}\stackrel{0}{1} \\
\text { in }\end{array}$ & $\stackrel{\overbrace{}}{\sim}$ & $\tilde{n}$ & $\stackrel{\text { nf }}{0}$ & $\begin{array}{l}\text { n़? } \\
\text { in }\end{array}$ & $\begin{array}{l}\stackrel{0}{+} \\
\stackrel{+}{d}\end{array}$ & $\begin{array}{l}\infty \\
\infty \\
i n\end{array}$ & $\hat{n}$ \\
\hline $\mathrm{N}_{3}$ & $\stackrel{n}{o}$ & $\stackrel{\Re}{\circ}$ & nิ & ñ. & of & $\begin{array}{l}R \\
i n\end{array}$ & $\hat{n}$ & $\tilde{n}$ & $\begin{array}{l}8 \\
\infty \\
\infty\end{array}$ & $\begin{array}{l}0 \\
\text { in. } \\
\infty \\
i\end{array}$ & రి & త్రి \\
\hline $\mathrm{N}_{4}$ & $\begin{array}{l}\delta \\
0 \\
0\end{array}$ & $\begin{array}{l}\stackrel{0}{\circ} \\
\stackrel{0}{0}\end{array}$ & ț & $\underset{\text { Ș }}{0}$ & $\stackrel{n}{n}$ & กิ & nิ & 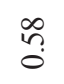 & $\begin{array}{l}\text { in } \\
\text { nn }\end{array}$ & f̊. & $\tilde{n}$ & $\stackrel{2}{\stackrel{2}{r}}$ \\
\hline
\end{tabular}

and unstressed leaves for different treatment combination on maize are presented in (Table 2). The spectral vegetation indices viz., NDVI, GNDVI, RVI, LCI, IR-RED and SR were recorded and the highest value of $0.91,0.77,20.04,0.78,35.36$, and 23.27 respectively were observed with irrigation at IW/ CPE ratio 0.80 with $100 \%$ RDN (unstressed) applied to maize crop. This may be attributed to the factor that due full supply of nitrogen and water were made to the plants. Maize under stress recorded reduced values of $0.78,0.58,7.43,0.53,26.09$ and 8.29 respectively when the crop was irrigated $0.50 \mathrm{IW} / \mathrm{CPE}$ ratio and applied with no nitrogen at $60 \mathrm{DAS}$ and the similar trend was noticed at 90 DAS.

\subsection{Relationship between spectral indices with different crop parameters}

The correlation coefficient between spectral indices and crop

\begin{tabular}{|c|c|c|c|c|c|c|c|c|c|c|}
\hline \multicolumn{11}{|c|}{$\begin{array}{l}\text { Table 3: Effec } \\
\text { value of hybr }\end{array}$} \\
\hline & & & & & & & & & & \\
\hline \multirow[b]{2}{*}{ 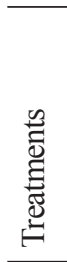 } & \multicolumn{3}{|c|}{$\begin{array}{l}\text { LAI } 60 \\
\text { DAS }\end{array}$} & \multicolumn{2}{|c|}{ LAI 90 DAS } & \multicolumn{2}{|c|}{$\begin{array}{c}\text { SPAD } 60 \\
\text { DAS }\end{array}$} & \multicolumn{3}{|c|}{$\begin{array}{c}\text { SPAD } 90 \\
\text { DAS }\end{array}$} \\
\hline & $\overline{\mathrm{W}_{1}}$ & $\mathrm{~W}_{2}$ & $\sum_{\bar{\Sigma}}^{\approx}$ & $\mathrm{W}_{1}$ & 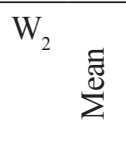 & $\mathrm{W}_{1}$ & 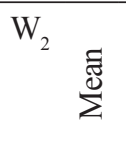 & $\mathrm{W}_{1}$ & $\mathrm{~W}_{2}$ & 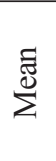 \\
\hline $\mathrm{N}_{0}$ & in & ते & 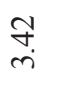 & $\stackrel{\infty}{\stackrel{\infty}{n}}$ & $\stackrel{m}{m} \vec{m}$ & $\underset{n}{n}$ & 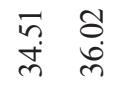 & $\underset{m}{\stackrel{\infty}{m}}$ & $\frac{\mathfrak{n}}{\dot{m}}$ & in \\
\hline $\mathrm{N}_{1}$ & $\stackrel{\mathbb{T}}{\stackrel{\sim}{+}}$ & $\stackrel{ }{i}$ & $\stackrel{\sim}{\sim}$ & in & in & 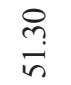 & $\begin{array}{ll}\tilde{n} & \bar{a} \\
\dot{q} & \ddot{q}\end{array}$ & $\begin{array}{l}\hat{\infty} \\
\dot{\sigma} \\
\dot{\sigma}\end{array}$ & 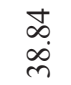 & $\begin{array}{l} \pm \\
\dot{f} \\
\dot{f}\end{array}$ \\
\hline $\mathrm{N}_{2}$ & $\vec{b}$ & $\underset{+}{\stackrel{+}{+}}$ & $\stackrel{n}{r}$ & $\begin{array}{l}\stackrel{+}{\infty} \\
+\end{array}$ & 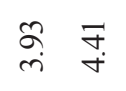 & $\begin{array}{l}\stackrel{1}{*} \\
i n\end{array}$ & $\begin{array}{ll}\infty & \stackrel{2}{\circ} \\
\dot{f} & \stackrel{q}{f}\end{array}$ & 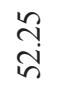 & $\stackrel{\stackrel{n}{F}}{F}$ & すे \\
\hline $\mathrm{N}_{3}$ & $\stackrel{\infty}{i}$ & $\vec{n}$ & $\underset{i}{8}$ & $\begin{array}{l}0 \\
\text { nn. } \\
n\end{array}$ & $\begin{array}{ll}\infty & \infty \\
\stackrel{+}{+} & \infty \\
+\end{array}$ & $\stackrel{2}{8}$ & $\begin{array}{ll}\bar{a} & \bar{n} \\
\tilde{g} & n\end{array}$ & $\stackrel{n}{n}$ & $\begin{array}{l}\frac{1}{\sigma} \\
\text { + }\end{array}$ & $\stackrel{\text { ते }}{\text { in }}$ \\
\hline $\mathrm{N}_{4}$ & ì & $\stackrel{\infty}{\stackrel{\leftrightarrow}{f}}$ & $\stackrel{\infty}{+}$ & $\begin{array}{l}\text { OS } \\
\text { in }\end{array}$ & 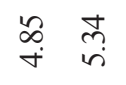 & 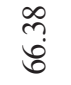 & $\begin{array}{ll}8 & 1 \\
i & 0 \\
i n & 8\end{array}$ & तิ & $\begin{array}{l}\stackrel{0}{a} \\
\text { in }\end{array}$ & $\stackrel{2}{\stackrel{i}{n}}$ \\
\hline$\sum^{\mathrm{E}}$ & 字 & $\stackrel{1}{F}$ & & \begin{tabular}{l}
$\mathscr{S}$ \\
\multirow{+}{+}{}
\end{tabular} & $\stackrel{\infty}{m}$ & $\begin{array}{l}\vec{\sim} \\
\stackrel{+}{n}\end{array}$ & $\begin{array}{l}\stackrel{+}{\Delta} \\
\dot{J}\end{array}$ & $\frac{d}{i n}$ & 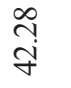 & \\
\hline & 鬲 & 8 & & 焉 & 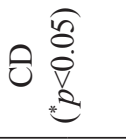 & Iت & 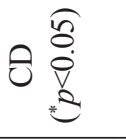 & 跔 & 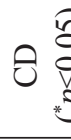 & \\
\hline W & $\stackrel{\infty}{\circ}$ & $\stackrel{\infty}{0}$ & & $\frac{1}{0}$ & $\hat{n}$ & $\hat{s}$ & $\vec{\sim}$ & $\stackrel{\infty}{-\infty}$ & $\stackrel{a}{c}$ & \\
\hline $\mathrm{N}$ & సู & 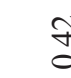 & & $\frac{2}{0}$ & $\vec{\sigma}$ & $\overrightarrow{\mathrm{N}}$ & $\stackrel{\nabla}{\forall}$ & $\vec{i}$ & s & \\
\hline $\begin{array}{l}\text { W } \\
\times \\
N\end{array}$ & సี & કั & & $\overrightarrow{\widetilde{o}}$ & $\stackrel{n}{\circ}$ & $\stackrel{\text { I }}{i}$ & $\frac{n}{n}$ & $\widetilde{\overbrace{}}$ & & \\
\hline
\end{tabular}




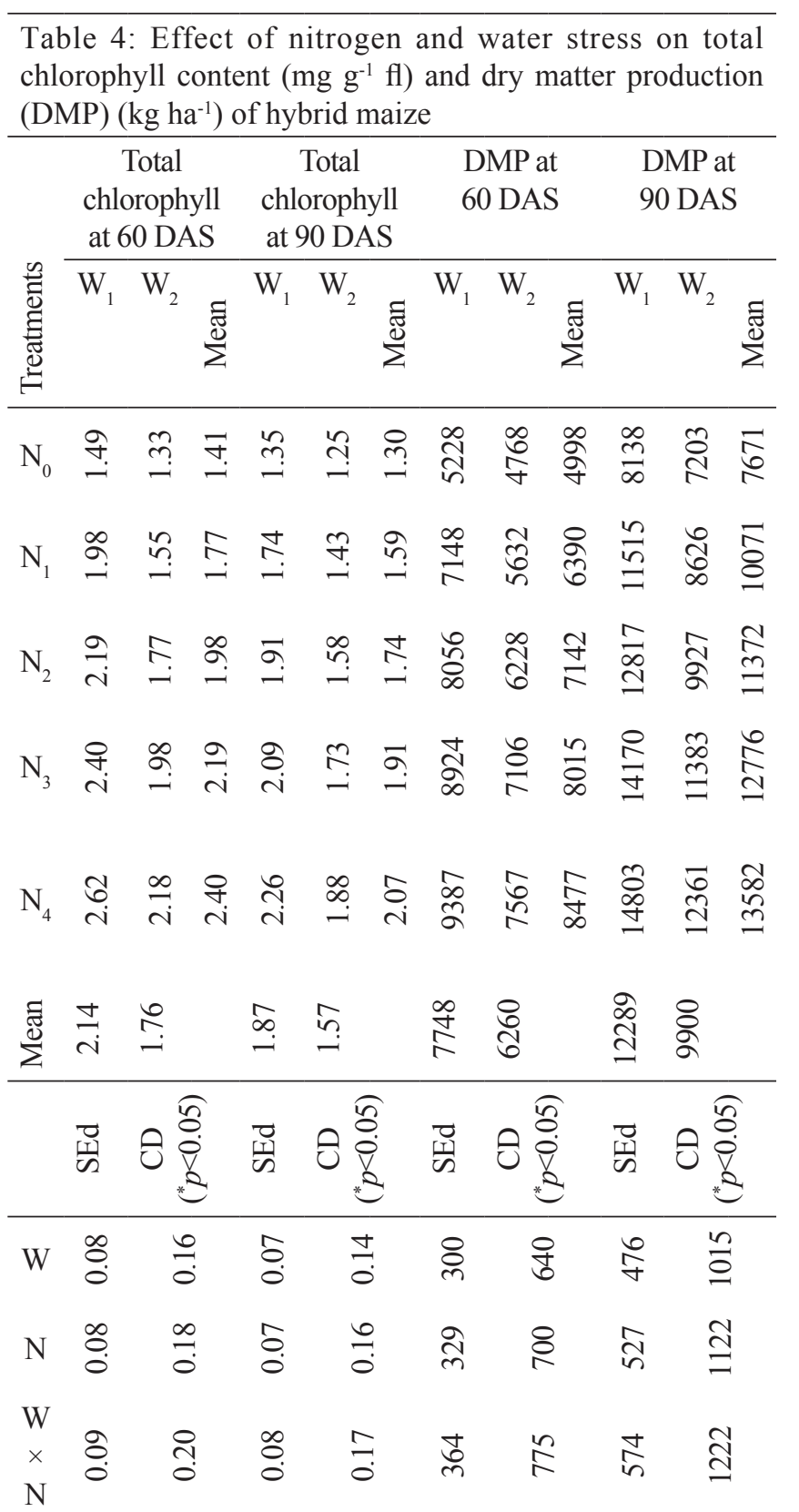

parameters at different plant growth stages are presented in (Table 3 and 4). Spectral indices recorded both at 60 and 90 DAS better correlated with crop parameters viz., Leaf area index, SPAD value and total chlorophyll content. The indices viz., NDVI, GNDVI, RVI, LCI, IR-RED and SR had better correlation with crop growth parameters. Especially all the spectral vegetation indices expressed high or positive correlation with LAI, SPAD value and total chlorophyll content with a correlation coefficient of $>0.80$ both at 60 and 90 DAS.

Prediction equations were developed between the GNDVI and measured LAI. The overall best fit was liner with a coefficient of determination of $\mathrm{R}^{2}$ value from 0.72 to $0.75 \%$. The prediction equation for LAI using GNDVI at 60 and 90 DAS are given in (Figure 4).

Prediction equations were developed between the GNDVI and measured total chlorophyll content. The overall best fit was linear with a coefficient of determination of $\mathrm{R}^{2}$ value from 0.77 to $0.78 \%$. The prediction equation for total chlorophyll content using GNDVI at 60 and 90 DAS are given in (Figure 4). Prediction equations were developed between the NDVI and measured DMP. The overall best fit was linear with a coefficient of determination of $\mathrm{R}^{2}$ value from 0.75 to $0.86 \%$. The prediction equation for DMP using NDVI at 60
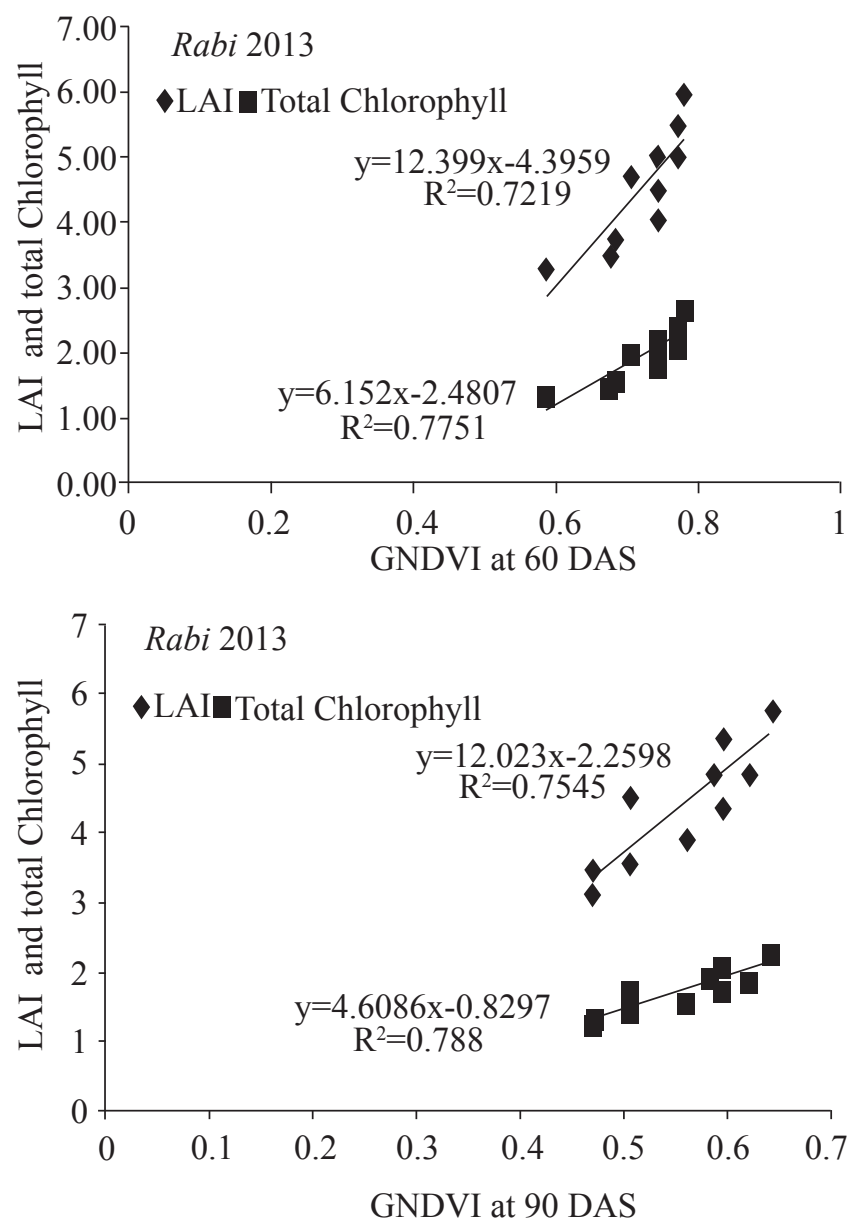

Figure 4: Relationship between GNDVI Vs LAI and Total chlorophyll content

and 90 DAS are given in (Figure 5).

Prediction equations were developed between the NDVI and measured grain yield. The overall best fit was linear with a coefficient of determination of $\mathrm{R}^{2}$ value from 0.79 to $0.83 \%$. The prediction equation for grain yield using NDVI at 60 and 90 DAS are given in (Figure 5). The results clearly indicated that the nitrogen and water stress could be estimated and 
Table 5: Correlation coefficients between spectral vegetation indices with LAI, SPAD value and total chlorophyll of nitrogen and water stress of hybrid maize

\begin{tabular}{lccllll}
\hline 60 DAS & \multicolumn{5}{c}{90 DAS } \\
\hline Indices & LAI & SPAD & $\begin{array}{l}\text { Total } \\
\text { chloro- } \\
\text { phyll }\end{array}$ & LAI & SPAD & $\begin{array}{l}\text { Total } \\
\text { chloro- } \\
\text { phyll }\end{array}$ \\
\hline NDVI & $.895^{* *}$ & $.814^{* *}$ & $.938^{* *}$ & $.938^{* *}$ & $.900^{* *}$ & $.926^{* *}$ \\
GNDVI & $.936^{* *}$ & $.852^{* *}$ & $.922^{* *}$ & $.906^{* *}$ & $.844^{* *}$ & $.895^{* *}$ \\
RVI & $.893^{* *}$ & $.841^{* *}$ & $.918^{* *}$ & $.901^{* *}$ & $.859^{* *}$ & $.894^{* *}$ \\
LCI & $.921^{* *}$ & $.841^{* *}$ & $.909^{* *}$ & $.895^{* *}$ & $.840^{* *}$ & $.883^{* *}$ \\
IR-RED & $.940^{* *}$ & $.864^{* *}$ & $.890^{* *}$ & $.919^{* *}$ & $.881^{* *}$ & $.921^{* *}$ \\
\hline SR & $.877^{* *}$ & $.826^{* *}$ & $.921^{* *}$ & $.904^{* *}$ & $.865^{* *}$ & $.898^{* *}$ \\
\hline
\end{tabular}
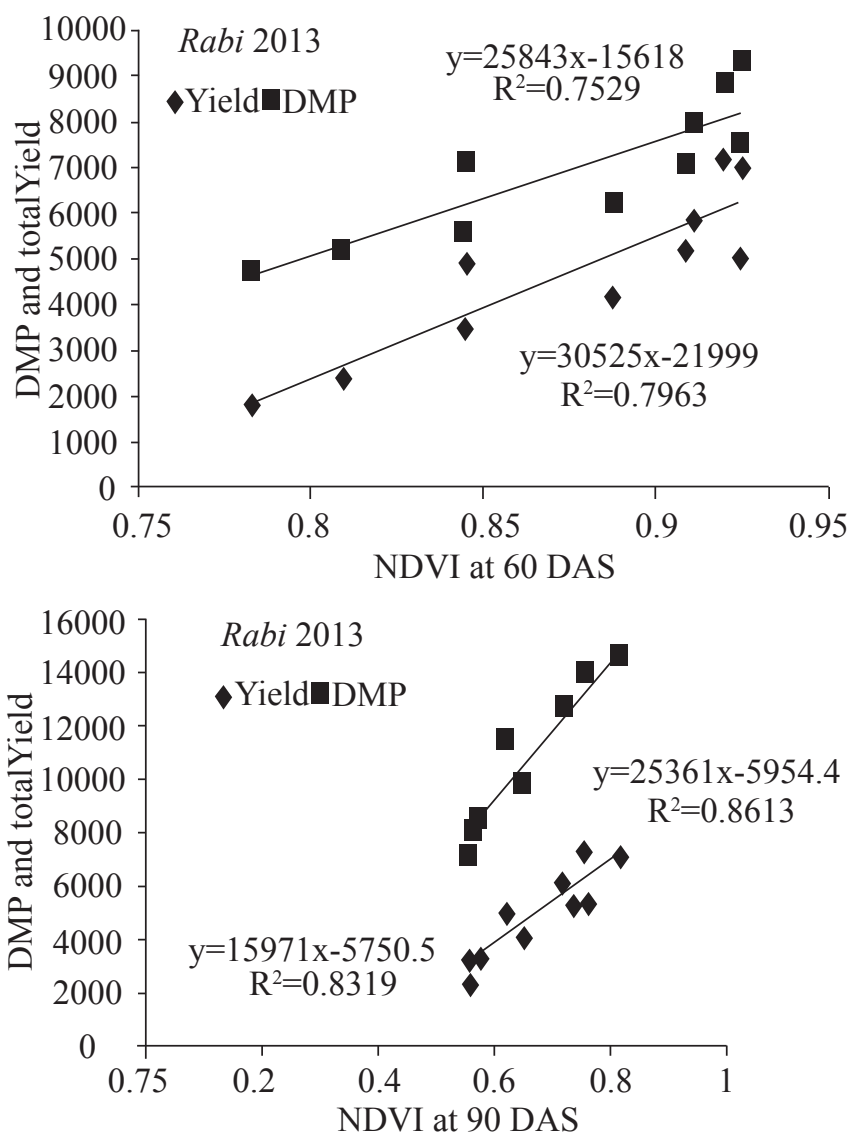

Figure 5: Relationship between NDVI Vs DMP and Yield of maize

quantified at large scale through vegetation indices derived from satellite driven remote sensing data over a large area.

\section{Conclusion}

To assess the combined effect of nitrogen and water stress in maize, hyper spectral reflectance value were transformed into spectral vegetation indices. All the spectral vegetation indices viz., NDVI, GNDVI, RVI, LCI, IR-RED and SR were highly or positively correlated $(>0.80)$ with LAI, SPAD value and total chlorophyll content at both the stages. This result indicates the ability of spectral vegetation indices to quantify the combine effect of nitrogen and water stress on maize too earlier through remote sensing.

\section{Acknowledgement}

This work has been undertaken with financially support from UGC, New Delhi under Major research projects scheme.

\section{References}

Anonymous, 2014. India maize summit'14 held on March 2021, 2014 at Federation of Indian Chamber of Commerce and Industry (FICCI), New Delhi, 3.

Aparicio, N., Villegas, D., Casadensus, J., Araus, L., Royo, C., 2000. Spectral vegetation indices as nondestructive tools for determining durum wheat yield. Agronomy Journal 92, 83-91.

Elmetwalli, A.M.H., Tyler, A.N., Hunter, P.D., Salt, C.A., 2012. Detecting and distinguishing moisture and salinity-induced stress in wheat and maize through in situ spectroradiometry measurements. Remote Sensing Letters 3, 363-372.

Genc, L., Demirel, K., Camoglu, G., Asik, S., Smith, S., 2011. Determination of plant water stress using spectral reflectance measurements in watermelon (Citrullus vulgaris). American-Eurasian Journal of Agriculture and Environmental Science 11(2), 296-304.

Genc, L., Inalpulat, M., Kizil, U., Mirik, M., Smith S.E., Mendes, M., 2013. Determination of water stress with spectral reflectance on sweet corn (Zea mays L.) using classification tree (CT) analysis. ZemdirbysteAgriculture 100(1), 81-90.

Gitelson, A.A., Merzlyak N., 1996. Signature analysis of leaf reflectance spectra: algorithm development for remote sensing of chlorophyll. Journal of Plant Physiology 148, 494-500.

Jayasree, G., Lingalah, D., Raji Reddy, D., Narasimha Rao, S.B.S., 2013. Relationship between biophysical parameters and normalized difference vegetation index in maize. Journal of Agrometeorology 15(2), 120-125.

Krezhova, D., 2011. Spectral Remote Sensing of the Responses of Soybean Plants to Environmental Stresses. In: Krezhova, D. (Ed.), Soybean-Genetics and Novel Techniques for Yield Enhancement. Available from: http://www.intechopen.com/books/soybean-geneticsand-noveltechniques-for-yield-enhancement/spectralremote-sensing-of-the-responses-of-soybean-plantstoenvironmental-stresses. 215-256. ISBN: 978-953307-721-5. 
Lillesand, T.M., Kiefer, R.W., 2000. Remote Sensing and Image Interpretation. $4^{\text {th }}$ edition. John Wiley and Sons, Inc., New York. 724.

Mirik, M., Ansley, R.J., Michels, Jr. G.J., Elliott, N.C., 2012. Spectral vegetation indices selected for quantifying Russian wheat aphid (Diuraphis noxia) feeding damage in wheat (Triticum aestivum L.). Precision Agriculture 13, 501-516.

Padilla, F.L.M., González-Dugo, M.P., Gavilán, P., Domínguez, J., 2011. Integration of vegetation indices into a water balance model to estimate evapo-transpiration of wheat and corn. Hydrology and Earth System Sciences 15, 1213-1225.

Panigada, C., Busetto, L., Meroni, M., Amaducci, S., Rossini, M., Cogliati, S., Boschetti, M., Picchi, V., Marchesi, A., Pinto, F., Rascher, U., Colombo, R., 2010. EDOCROS: Early detection of crop water and nutritional stress by remotely sensed indicators. In: $4^{\text {th }}$ International workshop on remote sensing of vegetation fluorescence, $15-17$ Nov.
2010, Valencia (SPAIN), 1-7.

Pradhan, S., Chopra, U.K., Bandyopadhyay, K.K., Krishnan, P., Singh, R., Jain, A.K., 2013. Soil water dynamics, root growth and water and nitrogen use efficiency of rainfed maize (Zea mays) in a semi-arid environment. Indian Journal of Agricultural Science 83(5), 542-548.

Rouse, J.W., Haas, R.H., Schell, J.D., Deering, J.A., 1973. Monitoring vegetation systems in the great plains with ERTS, In: Proceedings of third symposium on significant results obtained with ERTS-1, NASA. Goddard Space Flight Center: Greenbelt, MD, USA, 1, 309-317.

Szeles, A.V., Megyes, A., Nagy, J., 2012. Irrigation and nitrogen effects on the leaf chlorophyll content and grain yield of maize in different crop years. Agricultural Water Management 107, 133-344.

Thenkabail, P.S., Smith, R.B., Pauw, E.D., 2000. Hyperspectral vegetation indices for determining agricultural crop characteristics. Remote Sensing of Environment 71(2), 158-182. 